\title{
PENICILLIN-STREPTOMYCIN-GELATINE DISCS IN THE TREATMENT OF HYPOPYON ULCERS*
}

\author{
BY \\ A. D. GROVER \\ M.U. Institute of Ophthalmology, Aligarh, India
}

Mules (1894) wrote that "where the action of micro-organisms on an abraded surface may cause or is causing destructive changes, the indication would be to remove the irritating element and allow the natural process of repair to heal the breach of surface". Thus the best results are likely to be achieved by that mode of administration which will give the maximum concentration of the drug in the anterior segment of the eye, especially the cornea. Since the advent of the sulphonamides and antibiotics, attempts have been made to treat corneal ulcers by parenteral, subconjunctival, and topical administration of these drugs. Penicillin is active against Grampositive, and streptomycin mainly against Gram-negative organisms. The combination of these two antibiotics has a wide range of activity and has been commonly used in the treatment of corneal ulcers.

Streptomycin, being fat-insoluble, penetrates the permeable membranes with difficulty and its passage from plasma to aqueous is very poor. With systemic administration the concentration of streptomycin in the ocular tissues is very low (Leopold, 1950). The level of penicillin in the aqueous humour after massive systemic administration is distinctly lower than that obtained by subconjunctival injection or even by the use of penicillin ointment (Sorsby, 1948). The cornea has the added disadvantage that its nutrition is especially poor in the central part, where most of the ulcers occur. Penicillin and streptomycin administered systemically are, therefore, ineffective in the treatment of corneal ulcers, except in so far as they control the inflammation of the tissues around the eyeball.

Subconjunctival injections of the antibiotics give a suitable concentration in the eye for combating the intra-ocular infections and rapid improvement can be achieved in this way (Bignell, 1951; Clark and Locatcher-Khorazo, 1951; Sorsby and others, 1952). Penicillin (Sorsby and Ungar, 1948) and streptomycin (Sorsby, Ungar, and Bailey, 1952) are suitable for subconjunctival injection as they are readily soluble in water and only slightly irritant.

Penicillin and streptomycin penetrate the intact corneal epithelium with difficulty if administered as drops or ointment. When the epithelium is

* Received for publication January 25, 1960. 
abraded the penetration is considerably increased and one would therefore expect local treatment to be effective in corneal ulcers. Eyedrops disappear from the conjunctival sac in a matter of minutes and the optimum concentration for an adequate length of time is not obtainable in this way (Ridley, 1931). If ointments are used, the drug is embedded in the ointment base and its release from the latter is uncertain. In order to achieve good results large quantities of the drug should remain in contact with the ulcerated cornea for a long period. Cameron (1949) applied sulphacetamide powder locally to the cornea in cases of hypopyon ulcer and obtained good results; but these were all cases of "corneal abrasions which showed infiltration at the site of injury with an inflammatory reaction whether actual hypopyon was present or not". Juler and Young (1945) placed solid penicillin on infected corneal ulcers with encouraging results. Mules (1894) placed a gelatine wafer impregnated with iodoform on the ulcerated corneal surface with good results. Huber (1934) used a contact shell carrying iodoformcocaine dionine ointment for the treatment of corneal ulcers. Struble and Bellows $(1944,1946)$ have shown that a high concentration of penicillin in the anterior segment of the eye can be built up by the use of a corneal bath and they have advocated this procedure for the treatment of corneal ulcers, particularly if the deeper layers are involved. Klein and Millwood (1952) applied semisolid calcium alginate caps carrying chloramphenicol to rabbit eyes, but these caps caused slight irritation. However, streptomycin applied in glycerine-gelatine discs was found to be efficacious against experimental ocular infections (Klein and Millwood, 1953).

In view of the above findings we tried gelatine discs containing penicillin and streptomycin in a series of cases of hypopyon ulcer. The results were compared with a group of similar cases treated with subconjunctival injections of these antibiotics.

\section{Method}

At the Gandhi Eye Hospital, Aligarh, 32 cases of hypopyon ulcer were divided into two random groups (by the use of random sample numbers). In one group gelatine discs containing penicillin and streptomycin were applied locally thrice daily and the other group was given subconjunctival injections of $0.5 \mathrm{~g}$. streptomycin and 250,000 units penicillin with a few drops of mydricaine on alternate days. Bacteriological examination of the conjunctival sac and the ulcer area was done and the treatment was started immediately afterwards. The group treatment was continued whatever bacterial flora were present, because penicillin and streptomycin together are active against both Gram-positive and Gram-negative organisms. The treatment given to each case was determined solely by the random sample number. All the patients were given hot fomentations twice daily and 1 per cent. atropine ointment thrice daily. No other medication was administered locally or systemically. If improvement was not noticed within 48 hours of the start of the treatment the case was considered to be a 
failure for that group. The treatment was continued until the ulcer no longer stained with fluorescein. The time taken by the hypopyon, slough, and staining to disappear was recorded. The condition of the cornea and the visual acuity at the time of discharge were noted.

Preparation of Discs.-A 30 per cent. solution of gelatine was prepared and autoclaved. 20 g. of streptomycin and 20 million units penicillin were added to $100 \mathrm{ml}$. gelatine solution. A Perspex plate containing $10-\mathrm{mm}$. diameter holes rested on a sterile sheet of glass which was kept on ice. Gelatine solution containing the antibiotics was poured into the holes. The discs thus formed were stored at $4^{\circ} \mathrm{C}$. and were used within 7 to 10 days.

\section{Results}

Details of the cases of hypopyon ulcer treated are given in Tables I and II (overleaf).

Good Response.-Fourteen of the seventeen cases treated with penicillinstreptomycin-gelatine discs responded well (Table I). The hypopyon disappeared on an average in 3.61 days and corneal staining in 10.8 days. The mean visual acuity at the time of discharge was $3 \cdot 8 / 60$.

Ten out of fifteen cases $(66.6$ per cent.) treated with subconjunctival injections of penicillin and streptomycin also gave a good response (Table II). The average time taken by the hypopyon to disappear was 3.11 days and corneal staining 11.66 days. The mean visual acuity at the time of discharge was $3 \cdot 33 / 60$.

Satisfactory Response.-In Cases 10 and 12 (Table I), the immediate response was satisfactory. Hypopyon disappeared in 6 and 5 days respectively but the fluorescein staining persisted for more than 12 days and healing progressed very slowly. Carbolic cautery controlled the condition. Culture revealed $B$. proteus in each case.

Cases 8 and 9 (Table II) did not tolerate the repeated subconjunctival injections though the initial response was satisfactory, and the treatment had to be continued with gelatine discs. The hypopyon took 9 and 6 days respectively to disappear. The causative organism was found to be $P S$. pyocyaneus in Case 8 and Strept. viridans and Staph. aureus in Case 9.

Unsatisfactory Response.-Case 4 (Table I) did not show a satisfactory response to the disc treatment; subconjunctival injections of penicillin and streptomycin were given, but the condition continued to deteriorate, and finally the eye had to be eviscerated. The causative organism was $P S$. pyocyaneus.

In Cases 10, 12, and 15 (Table II) the response after 48 hours was not satisfactory. In Case 10 carbolic cautery was done and in the others gelatine discs controlled the condition. The causative organism was Ps. pyocyaneus in Case 10 and Staph. albus in Case 12. Case 15 developed signs of panophthalmitis $24 \mathrm{hrs}$ after the first subconjunctival injection, the pathogenic organism being Pneumococcus. 
TABLE Iİ SEVENTEEN CASES OF HYPOPYON ULCER TREATED BY GELATINE

\begin{tabular}{|c|c|c|c|c|c|c|c|}
\hline $\begin{array}{l}\text { Case } \\
\text { No. }\end{array}$ & $\begin{array}{l}\text { Age } \\
\text { (yrs) }\end{array}$ & Sex & $\begin{array}{c}\text { Duration of } \\
\text { Disease (days) }\end{array}$ & $\begin{array}{l}\text { Degree of } \\
\text { Hypopyon }\end{array}$ & $\begin{array}{l}\text { Degree of } \\
\text { Slough }\end{array}$ & $\begin{array}{l}\text { Organisms Cultured from } \\
\text { Corneal Ulcer }\end{array}$ & $\begin{array}{l}\text { No. of } \\
\text { Days Discs } \\
\text { were Applied }\end{array}$ \\
\hline 1 & 30 & $\mathbf{M}$ & 12 & + & - & Sterile & 9 \\
\hline 2 & 60 & $\mathbf{M}$ & 10 & + & ++ & Staph. albus & 10 \\
\hline 3 & 17 & $\mathbf{M}$ & 10 & +++ & +++ & Ps. pyocyaneus & 15 \\
\hline 4 & 40 & $\mathbf{M}$ & 30 & +++ & ++ & $\begin{array}{l}\text { Ps. pyocyaneus } \\
\text { Staph. albus }\end{array}$ & 10 \\
\hline 5 & 30 & $\mathbf{M}$ & 3 & ++ & ++ & $\begin{array}{l}\text { B. proteus } \\
\text { Diphtheroids }\end{array}$ & 8 \\
\hline 6 & 55 & $\mathbf{M}$ & 7 & + & + & Ps. pyocyaneus & 12 \\
\hline 7 & 30 & F & 15 & ++ & ++ & $\begin{array}{l}\text { Staph. albus } \\
\text { Staph. aureus (coagulase- } \\
\text { positive) }\end{array}$ & 18 \\
\hline 8 & 30 & $\mathbf{M}$ & 5 & + & ++ & Ps. pyocyaneus & 11 \\
\hline 9 & 55 & $\mathbf{M}$ & 10 & + & + & Sterile & 10 \\
\hline 10 & 30 & $\mathbf{F}$ & 14 & ++ & ++ & $\begin{array}{l}\text { B. proteus } \\
\text { Staph. albus }\end{array}$ & 14 \\
\hline 11 & 25 & F & 7 & +++ & ++ & $\begin{array}{l}\text { Ps. pyocyaneus } \\
\text { Staph. albus }\end{array}$ & 9 \\
\hline 12 & 22 & $\mathbf{M}$ & 5 & + & ++ & $\begin{array}{l}\text { B. proteus } \\
\text { Staph. albus }\end{array}$ & 12 \\
\hline 13 & 30 & $F$ & 3 & + & + & Strept. viridans & 8 \\
\hline 14 & 30 & $\mathbf{M}$ & 15 & ++ & + & $\begin{array}{l}\text { Staph. aureus } \\
\quad \text { (coagulase-positive) }\end{array}$ & 16 \\
\hline 15 & 40 & $\mathbf{M}$ & 15 & + & - & $\begin{array}{l}\text { Staph. aureus (coagulase- } \\
\text { positive) } \\
\text { Diphtheroids }\end{array}$ & 7 \\
\hline 16 & 5 & $\mathbf{F}$ & 1 & + & - & $\begin{array}{l}\text { Pneumococcus } \\
\text { Staph. aureus }\end{array}$ & 6 \\
\hline 17 & 16 & $\mathbf{M}$ & 5 & +++ & +++ & Ps. pyocyaneus & 16 \\
\hline
\end{tabular}

Degrees of Hypopyon $\left\{\begin{array}{l}+=t \text { or less of anterior chamber } \\ +++=+ \text { to }\end{array}\right.$

$++=$ More than $\frac{1}{2}$ ol anterior chamber 
DISCS CONTAINING PENICILLIN AND STREPTOMYCIN

\begin{tabular}{|c|c|c|c|c|c|}
\hline $\begin{array}{l}\text { Duration of } \\
\text { Hypopyon } \\
\text { (days) }\end{array}$ & $\begin{array}{c}\text { Duration of } \\
\text { Slough } \\
\text { (days) }\end{array}$ & $\begin{array}{c}\text { Duration of } \\
\text { Staining } \\
\text { (days) }\end{array}$ & $\begin{array}{c}\text { Visual Acuity } \\
\text { on } \\
\text { Discharge }\end{array}$ & $\begin{array}{c}\text { Final Condition } \\
\text { of Eye }\end{array}$ & Remarks \\
\hline 3 & - & 9 & $6 / 60$ & Diffuse nebula & \\
\hline 3 & 5 & 10 & $3 / 60$ & Diffuse nebula & \\
\hline 5 & 7 & 14 & $\begin{array}{c}\text { Hand } \\
\text { movements }\end{array}$ & Dense leucoma & \\
\hline Present & Present & 一 & - & - & $\begin{array}{l}\text { Also given subcon- } \\
\text { junctival injections } \\
\text { but panophthalm- } \\
\text { itis developed. } \\
\text { Evisceration was } \\
\text { required }\end{array}$ \\
\hline 4 & 4 & 8 & $5 / 60$ & Macular opacity & \\
\hline 3 & 5 & 12 & $3 / 60$ & Central leucoma & \\
\hline 5 & 7 & 16 & $3 / 60$ & $\begin{array}{l}\text { Leucomatous } \\
\text { opacity }\end{array}$ & \\
\hline 3 & 4 & 10 & $3 / 60$ & Leucoma & \\
\hline 2 & 3 & 9 & $4 / 60$ & Macular opacity & \\
\hline 6 & 12 & 29 & $\begin{array}{l}\text { Counting } \\
\text { fingers }\end{array}$ & Dense leucoma & $\begin{array}{l}\text { Carbolic cautery } \\
\text { done }\end{array}$ \\
\hline 7 & 6 & $\begin{array}{l}\text { Present on } \\
10 \text { th day }\end{array}$ & - & - & $\begin{array}{l}\text { Patient left against } \\
\text { medical advice }\end{array}$ \\
\hline 5 & $\begin{array}{l}\text { Present after } \\
12 \text { days }\end{array}$ & $\begin{array}{l}\text { Present on } \\
\text { 12th day }\end{array}$ & $\begin{array}{c}\text { Hand } \\
\text { movements }\end{array}$ & Dense leucoma & $\begin{array}{l}\text { Carbolic cautery } \\
\text { done }\end{array}$ \\
\hline 2 & 3 & 8 & $5 / 60$ & Macular opacity & \\
\hline 5 & 4 & 14 & $4 / 60$ & Macular opacity & \\
\hline 3 & 一 & 6 & $6 / 36$ & Nebular opacity & 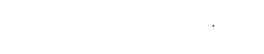 \\
\hline 2 & - & 6 & $\begin{array}{c}\text { Hand } \\
\text { movements }\end{array}$ & Clear & $\begin{array}{c}\text { Traumatic } \\
\text { cataract }\end{array}$ \\
\hline 7 & 8 & 14 & $\begin{array}{c}\text { Hand } \\
\text { movements }\end{array}$ & Dense leucoma & \\
\hline
\end{tabular}

Degrees of Slough $\left\{\begin{array}{l}+=\neq \text { or less of corneal surface } \\ ++\end{array}\right.$

$++=$ to $\frac{1}{2}$ of corneal surface
$+++=$ More than $\frac{1}{2}$ of corneal surface 
FIFTEEN CASES OF HYPOPYON ULCER TREATED BY

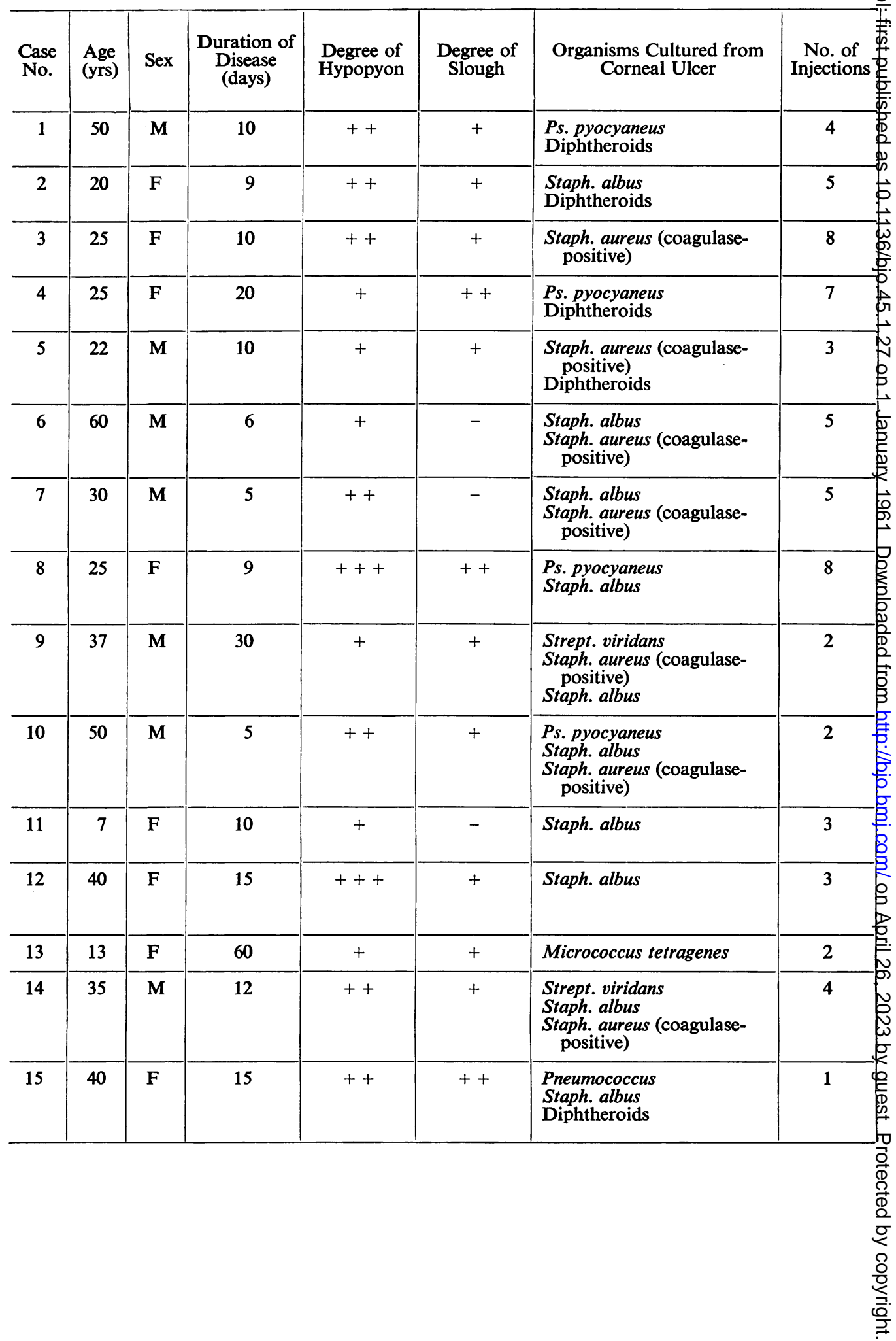


SUBCONJUNCTIVAL INJECTIONS OF PENICILLIN AND STREPTOMYCIN

\begin{tabular}{|c|c|c|c|c|c|}
\hline $\begin{array}{l}\text { Duration } \\
\text { of } \\
\text { Hypopyon } \\
\text { (days) }\end{array}$ & $\begin{array}{l}\text { Duration } \\
\text { of } \\
\text { Slough } \\
\text { (days) }\end{array}$ & $\begin{array}{l}\text { Duration } \\
\text { of } \\
\text { Staining } \\
\text { (days) }\end{array}$ & $\begin{array}{l}\text { Visual Acuity } \\
\text { on Discharge }\end{array}$ & $\begin{array}{l}\text { Final Condition } \\
\text { of Eye }\end{array}$ & Remarks \\
\hline 3 & 3 & 10 & $2 / 60$ & Macular opacity & \\
\hline 4 & 5 & 12 & $3 / 60$ & $\begin{array}{l}\text { Central macular } \\
\text { opacity }\end{array}$ & \\
\hline 4 & 4 & 18 & $\begin{array}{l}\text { Hand } \\
\text { movements }\end{array}$ & $\begin{array}{l}\text { Leucomatous } \\
\text { opacity }\end{array}$ & \\
\hline 2 & 10 & 15 & $1 / 60$ & Central leucoma & \\
\hline 3 & 3 & 6 & $6 / 36$ & Nebular opacity & \\
\hline 2 & 一 & 9 & $\begin{array}{l}\text { Perception of } \\
\text { light }\end{array}$ & Nebular opacity & Mature cataract \\
\hline 6 & - & 12 & $3 / 60$ & Macular opacity & \\
\hline 9 & 5 & 35 & Counting fingers & Dense leucoma & $\begin{array}{l}\text { Did not tolerate injections; } \\
\text { Terramycin ointment given } \\
\text { afterwards }\end{array}$ \\
\hline 6 & 10 & 15 & Counting fingers & Dense leucoma & $\begin{array}{l}\text { Did not tolerate injections; } \\
\text { gelatine discs given. }\end{array}$ \\
\hline 8 & 9 & 16 & $\begin{array}{c}\text { Hand } \\
\text { movements }\end{array}$ & Central leucoma & $\begin{array}{l}\text { Hypopyon increased } \\
\text { Carbolic cautery done }\end{array}$ \\
\hline 2 & 一 & 8 & $\begin{array}{c}\text { Hand } \\
\text { movements }\end{array}$ & Clear & $\begin{array}{l}\text { Had trauma by needle } \\
\text { Developed cataract }\end{array}$ \\
\hline 16 & 10 & 29 & $\begin{array}{l}\text { Perception of } \\
\text { light }\end{array}$ & Dense leucoma & $\begin{array}{l}\text { No improvement from injec- } \\
\text { tions } \\
\text { Ulcer arrested by gelatine discs }\end{array}$ \\
\hline 2 & 3 & 10 & $6 / 60$ & Nebular opacity & \\
\hline 4 & 4 & +on 10th & - & 一 & $\begin{array}{l}\text { Patient left against medical } \\
\text { advice }\end{array}$ \\
\hline - & 一 & - & - & - & $\begin{array}{l}\text { Hypopyon increased } \\
\text { Signs of panophthalmitis de- } \\
\text { veloped }\end{array}$ \\
\hline
\end{tabular}




\section{Tolerance and Application.}

The discs caused no irritation and were well tolerated by all the patients. The eye was usually white at the time of discharge.

The application of the discs was simple as they could be easily slipped in under the eyelids which were then immediately bandaged. The only difficulty was that in very hot weather they melted too quickly. They were not spoiled by 7 to 10 days of storage; Klein and Millwood (1953) stored streptomycin-glycerine-gelatine discs for 30 days without loss of potency.

In spite of adding a few drops of mydricaine, the subconjunctival injections were painful, especially when they had to be repeated. The more the conjunctival inflammation the greater the pain. Conjunctival congestion persisted longer at the site of injection and a few petechial subconjunctival haemorrhages occurred.

Two patients who refused the injections easily tolerated the discs.

Table III shows a comparison of the results of the two types of treatment. In cases of mild and moderate degree of hypopyon $(+$ and ++$)$ the average time taken by the hypopyon to disappear was slightly less in cases treated with subconjunctival injections; but corneal staining disappeared sooner and the average final visual acuity was better in cases treated with discs. In cases of severe hypopyon the response to the discs was satisfactory, but the subconjunctival injections failed. Thus the overall results with the disc treatment were slightly better, and the discs were well tolerated even by acutely inflamed eyes.

\section{Discussion}

The value of subconjunctival injections of penicillin and streptomycin in the treatment of hypopyon ulcers is well established (Sorsby and Reed,

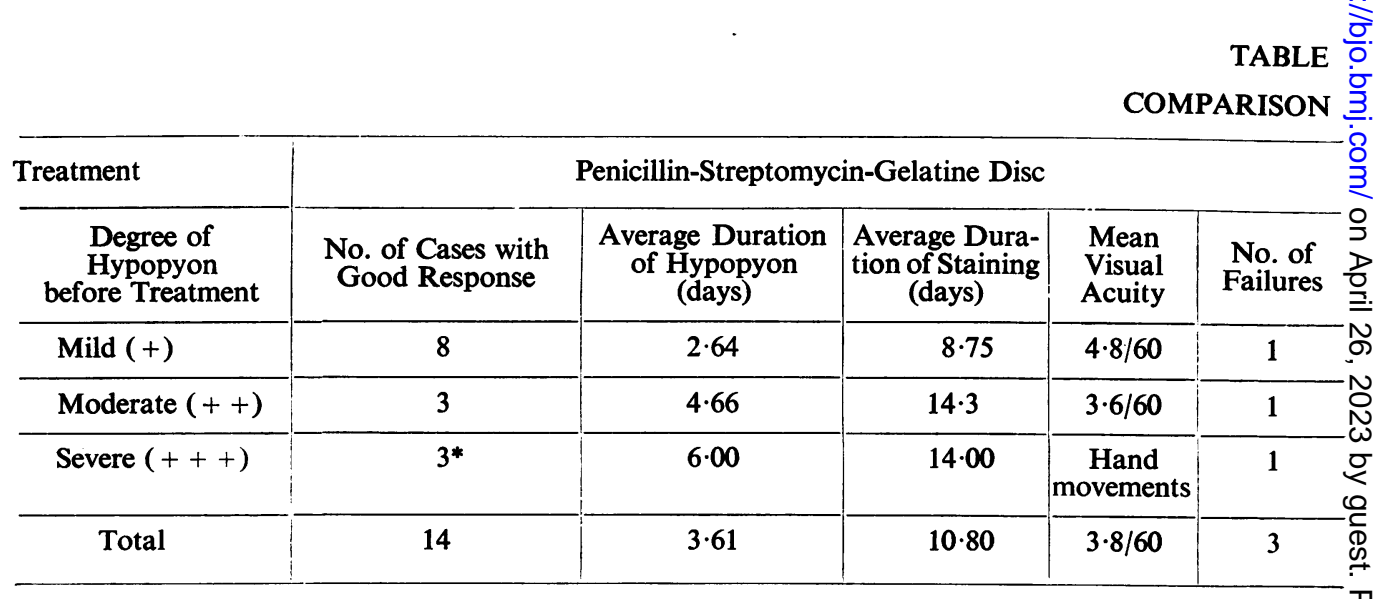

* One patient (No. 11) left against medical advice. 
1947; Sundaresan, 1949; Sorsby and Burn, 1950; Sorsby, Ungar, and Bailey, 1952).

Klein and Millwood (1953) found streptomycin-glycerine-gelatine discs efficacious against experimental corneal ulcers produced by Ps. pyocyaneus; only one-fifth of the quantity of streptomycin required for subconjunctival injections was necessary when administered in glycerine-gelatine discs.

The results in a series of cases treated with penicillin-streptomycin-gelatine discs show that they are efficacious in the treatment of hypopyon ulcers. Healing occurred more quickly and the final visual acuity was better. By this method the antibiotic has a longer contact with the ulcerated cornea, and the micro-organisms are destroyed sooner, producing the ideal conditions for repair stated by Muler (1894). The slightly earlier disappearance of hypopyon in cases treated with subconjunctival injections may be due to the higher concentration of the antibiotics in the aqueous which is obtained. The discs cause no irritation and are well tolerated even by acutely inflamed eyes, which is not the case with subconjunctival injections.

\section{Summary}

Thirty-two cases of hypopyon ulcer of the cornea were divided into two random groups, one treated by penicillin-streptomycin-gelatine discs and the other by subconjunctival injections of penicillin and streptomycin.

The medicated gelatine discs are easy to apply and are well tolerated by all patients, and the results obtained are as good or even slightly better than those obtained by subconjunctival injections.

I am grateful to Prof. B. R. Shukla, Director of the Institute, and Dr. Mohan Lal, Chief Medical Officer, Gandhi Eye Hospital, Aligarh, for their co-operation; to Dr. K. C. Agarwal for the bacteriological examination of the cases, to Dr. Hamida Saiduzzafar for her help, to Mr. J. P. Bansal for statistical assistance, and to Mr. K. C. Sharma for his help.

The Uttar Pradesh Scientific Research Committee gave financial aid for this work.

III

OF RESULTS

\begin{tabular}{|c|c|c|c|c}
\hline \multicolumn{3}{|c}{ Penicillin-Streptomycin Subconjunctival Injection } \\
\hline $\begin{array}{c}\text { No. of Cases with } \\
\text { Good Response }\end{array}$ & $\begin{array}{c}\text { Average Duration of } \\
\text { Hypopyon (days) }\end{array}$ & $\begin{array}{c}\text { Average Duration } \\
\text { of Staining } \\
\text { (days) }\end{array}$ & $\begin{array}{c}\text { Mean Visual } \\
\text { Acuity }\end{array}$ & $\begin{array}{c}\text { No. of } \\
\text { Failures }\end{array}$ \\
\hline 5 & $2 \cdot 22$ & $9 \cdot 60$ & $4 \cdot 2 / 60$ & 1 \\
\hline $5 \dagger$ & $4 \cdot 22$ & $14 \cdot 22$ & $2 \cdot 2 / 60$ & 2 \\
\hline- & - & - & - & 2 \\
\hline 10 & $3 \cdot 11$ & 11.66 & $3 \cdot 33 / 60$ & 5 \\
\hline
\end{tabular}

† One patient (No. 14) left against medical advice. 


\section{REFERENCES}

Bignell, J. L. (1951). Brit. J. Ophthal., 35, 419.

CAMERON, E. H. (1949). Ibid., 33, 368.

ClarK, G., and Locatcher-Khorazo, D. (1951). A.M.A. Arch. Ophthal., 45, 165.

Huber, E. (1934). Arch. Oftal. B. Aires, 9, 317.

JuLER, F., and Young, M. Y. (1945). Brit. J. Ophthal., 29, 312.

KLEIN, M., and Millwood, E. G. (1952). Ibid., 36, 679.

(1953). Ibid., 37, 30.

Mules, B. (1894). "Trans. VIII Int. Ophthal. Congr. Edinburgh", p. 60. Cited by Klein and Millwood (1953).

RIDLeY, F. (1931). Proc. roy. Soc. Med., 25, 480.

SORSBY, A. (1948). "Modern Trends in Ophthalmology", p. 397. Butterworth, London. and BURN, R. A. (1950). Brit. J. Ophthal., 34, 16. and UNGAR, J. (1948). Ibid., 32, 864.

$\longrightarrow$, and BAILEY, N. L. (1952). Brit. med. J., 1, 119.

Struble, G. C., and Bellows, J. G. (1944). J. Amer. med. Ass., 125, 685.

(1946). Arch. Ophthal. (Chicago), 35, 173.

Sundaresan, S. (1949). Proc. All-India ophthal. Soc., 10, 133. 